\title{
Mariana Mota Prado* THE PARADOX OF RULE OF LAW REFORMS: HOW EARLY REFORMS CAN CREATE OBSTACLES TO FUTURE ONES ${ }^{\dagger}$
}

In their most recent book, Rule of Law Reform and Development: Charting the Fragile Path of Progress, Michael Trebilcock and Ron Daniels show how rule of law reforms have a mixed - not to say disappointing - track record of successes. Their diagnosis is that social-historical-cultural factors and resistance from interest groups are two of the main obstacles to reform. This essay explores these two obstacles in greater depth. With respect to social-historical-cultural factors, my main argument is that early rule of law reforms can create values, practices, and attitudes that may become impediments to future reforms. On the political economy front, these early reforms can strengthen interest groups that will block future reforms. As a consequence, policy makers face a paradox: robust rule of law reforms early on may undermine broader reform efforts by reducing the possibility of other necessary reforms down the road, creating a reform trap. I illustrate the paradox with a Brazilian case study and discuss possible strategies to address this challenge.

Keywords: judicial reforms/development/rule of law/path dependence/ Brazil

\section{Introduction}

Beginning in the 1990s, an institutional perspective on development has become increasingly prominent in development thinking, captured in the mantra 'Institutions Matter' or 'Governance Matters.' ${ }^{\text {' Based on }}$ this assumption that 'institutions matter,' there has been a massive surge in development assistance for institutional reform projects in developing and transition economies, involving investments of many billions of dollars. Among these, law reform projects have acquired special

* Assistant Professor, Faculty of Law, University of Toronto.

$\dagger$ I am grateful to Diego Werneck Arguelhes, Kevin Davis, Diana Juricevic, Karen Knop, Julia Cadaval Martins, Michael Trebilcock, Ilton Robl Filho, and two anonymous reviewers for helpful comments and suggestions. Many thanks to Patricia Galvao Ferreira and Natasha Kanerva for outstanding research assistance. Eventual errors are my responsibility.

1 This is largely based on the work of Douglass North, a founder of the school of thought that became known as the New Institutional Economics. Some of North's most relevant pieces are Douglass C. North, Institutions, Institutional Change and Economic Performance (Cambridge: Cambridge University Press, 1990), and Douglass C. North, 'The New Institutional Economics' (1986) J.Inst.\& Theor.Econ. 142. 
importance. For instance, since 1990 the World Bank has supported 330 rule of law projects and spent us $\$ 2.9$ billion in this sector. ${ }^{2}$

However, these reforms have had mixed to disappointing results thus far, as Michael Trebilcock and Ron Daniels demonstrate in their recent book, Rule of Law Reform and Development: Charting the Fragile Path of Progress. ${ }^{3}$ Discussing numerous cases of failed reform in Africa, Asia, Latin America, and Eastern Europe, they show that we still know very little about how to conduct successful institutional reforms. And they are not alone: others have voiced similar concerns. ${ }^{4}$

Based on a wide array of case studies, Trebilcock and Daniels offer some insights into possible reasons for these failures. According to them, there are three main obstacles to reform. First, despite political will to promote reform, countries may lack the necessary financial, technological, or human resources to implement changes. Second, there may be 'social-cultural-historical factors that have yielded a set of social values, norms, attitudes, or practices that are inhospitable to even a limited conception of the rule of law. ${ }^{5}$ Third, there are politicaleconomy-based impediments. Groups of interests will resist reforms that eliminate their privileges, do not foster their interests, or do not offer them any gains (material or otherwise) ${ }^{6}$

My main argument here is that these obstacles can also be created by piecemeal rule of law reforms. ${ }^{7}$ Whenever reforms are made in instalments, instead of being full-fledged reforms, early institutional changes can generate two consequences: (1) the creation of practices, values, and attitudes that will block future reforms; and/or (2) the strengthening of interest groups that will resist future reforms. To illustrate the problem,

2 David Trubek, 'The Rule of Law in Development Assistance: Past, Present and Future' in David Trubek \& Alvaro Santos, eds., The New Law and Economic Development: A Critical Appraisal (Cambridge: Cambridge University Press, 2006) 74 at 74.

3 Michael Trebilcock \& Ron Daniels, Rule of Law Reform and Development: Charting the Fragile Path of Progress (Cheltenham, UK: Edward Elgar, 2008) [Trebilcock \& Daniels, Rule of Law].

4 Thomas Carothers, 'The End of the Transition Paradigm' (2002) 13 J.Democracy 5; Thomas Carothers, 'The Rule of Law Revival' (1998) 77 For.Aff. 95; Bryant Garth \& Yves Dezalay, 'Introduction' in Yves Dezalay \& Brian Garth, eds., Global Prescriptions: The Production, Exportation and Importation of a New Legal Orthodoxy (Ann Arbor: University of Michigan Press, 2002); Brian Tamanaha, On the Rule of Law: History Politics, Theory (Cambridge: Cambridge University Press, 2004); Brian Z. Tamanaha, 'The Primacy of Society and the Failure of Law and Development' (St. John's Legal Studies Research Paper No. 09-0172, 2009), online: Social Science Research Network $<$ http://papers.ssrn.com/sol3/papers.cfm?abstract_id=1406999 $>$.

5 Trebilcock \& Daniels, Rule of Law, supra note 3 at 39.

6 Ibid. at 39-40.

7 The words 'piecemeal' and 'sequenced' are used interchangeably in this essay, in contrast to full-fledged, all-encompassing, and comprehensive reforms. For a definition of the terms see notes 44 and 58 infra and accompanying text. 
I discuss a case study from Brazil. The Brazilian judiciary was granted strong guarantees of independence in 1988, when the new constitution was enacted. Attempts to promote statutory and constitutional reforms designed to improve the functioning of the Brazilian judiciary and to increase its accountability began as early as 1992, but judges strongly resisted these reforms. This resistance was effective until 2004, when a constitutional amendment was finally approved.

The Brazilian case shows that piecemeal or sequenced reforms can undermine the entire reform process because initial steps toward reforms may impair further institutional improvements. This is what I call a reform trap (see Part II below). Given that this problem is caused in part by the decision to implement sequenced or piecemeal reforms, can we conclude that avoiding sequenced or piecemeal reforms is the best strategy to reduce the risk of a reform trap? In principle, the answer is yes. However, those promoting more ambitious reforms need to be attentive to some of the risks of comprehensive and full-fledged reforms. And although this might be the solution in principle, in some cases sequenced reforms may be the only option available to reformers (see Part III below). Is there a way out of reform traps? The Brazilian case suggests that there is. After discussing some of the suggestions that Trebilcock and Daniels have made to overcome obstacles to reforms, I add some of my own, and highlight one that is not largely explored in the literature: changing the mindset or the preferences of the group that is strongly resisting reforms (see Part IV).

The analysis developed below largely builds on my work in collaboration with Michael Trebilcock. We have developed an argument in favour of piecemeal and sequenced reforms in a recent paper entitled 'Path Dependence, Development and the Dynamics of Institutional Reforms. ${ }^{8}$ In contrast, in this article I call attention to a potential problem with piecemeal or sequenced reforms: early reforms becoming obstacles to subsequent reforms. Nevertheless, I do not conclude that all-encompassing reforms would be preferable to sequenced ones. On the contrary, the risks of piecemeal reforms should be weighed against the risks of all-encompassing reforms, which are not negligible.

I also suggest here that despite the risk of reform traps, piecemeal reforms may sometimes be the only option available. In our paper on path dependence, Trebilcock and I analyse the advantages of piecemeal reforms vis-à-vis all-encompassing reforms during what we call 'normal times.' Our conclusion is that ambitious reforms are unlikely to be feasible or to succeed during normal times, because they will engender

8 Mariana Mota Prado \& Michael Trebilcock, 'Path Dependence, Development, and the Dynamics of Institutional Reform' (2009) 59 U.T.L.J. 341 [Prado \& Trebilcock, 'Path Dependence']. 
greater disruption and, therefore, more resistance. The scenario is different during abnormal times (which include times of economic collapse, major political crises, civil wars, and military invasions), because the credibility and legitimacy of the incumbent elites may be weakened and established patterns of social behaviour disrupted. In such cases, more ambitious and comprehensive reforms may become possible. However, we acknowledge that even in abnormal times, there may be path dependency problems. ${ }^{9}$ In this article, I unpack this claim by exploring some of the pre-existing economic, social, and cultural factors that may create obstacles to reform in abnormal times. More specifically, I discuss which factors can make ambitious and comprehensive reforms costly, risky, and sometimes unfeasible, even during times when there is supposedly a 'window of opportunity' for major reforms. I illustrate this using the Brazilian case.

\section{Case study: Reforming the Brazilian judiciary}

From independence in 1822 to the end of the latest military dictatorship in 1985, the history of the Brazilian judiciary has oscillated between gains in formal independence and recurrent backlashes and interference from the executive and legislative branches in the de facto independence of judges. ${ }^{10}$ Breaking this pattern was one of the major concerns of the reformers in the 1987/1988 Constitutional Assembly, who had especially vivid memories of the measures to reduce judicial independence that occurred between 1964 and 1985. ${ }^{11}$ To address this concern, the reformers decided to ensure high levels of judicial independence, both to protect the judiciary from external political interference and to allow it to serve as an effective instrument of horizontal accountability, securing a system of checks and balances that would control potential political abuses from the executive and legislative powers.

The institutional design to guarantee judicial independence in Brazil granted financial and administrative autonomy to the judiciary and expanded its powers of constitutional review. The 1988 reforms were highly successful in securing a high level of judicial independence in the Brazilian judiciary, as measured by autonomous rulings on politically sensitive issues and by its functional insulation from external

9 Ibid. at 370.

10 Martonio Lima, 'Judiciário e Estado no Brasil: Tribunais Superiores e Juízes na Formação do Estado Brasileiro’ (2000) 5 Pensar 5.

11 For a summary see William C. Prillaman, The Judiciary and Democratic Decay in Latin America: Declining Confidence in the Rule of Law (Westport, CT: Praeger, 2000) at 77-8 [Prillaman, Democratic Decay]. 
interference. ${ }^{12}$ Soon after the Constitution was enacted, however, the shortcomings of the model came to light. While the Brazilian institutional design brought unprecedented strength and political power to Brazilian judges and courts, this power was largely left unchecked by the lack of mechanisms to ensure accountability. ${ }^{13}$ Attempts to implement a second generation of reforms, including mechanisms of judicial accountability, began as early as 1992, only four years after the Constitution was enacted. Nevertheless, it took fifteen years for the first meaningful changes to be incorporated in the Brazilian system. In this section, I suggest that the difficulties of adopting a second generation of reforms in the Brazilian judiciary may have been rooted in - or compounded by - vested interests and a set of values created by the first generation of reforms. In order to develop this argument I will focus on one element of the second generation of reforms: the attempt to create external judicial oversight in Brazil.

\section{A THE 1988 REFORMS: JUDICIAL INDEPENDENCE WITHOUT EXTERNAL OVERSIGHT}

The 1988 Brazilian constitution maintained, strengthened, and incorporated a series of guarantees to protect judicial independence. To avoid political interference via financial constraints or threats, the judiciary was granted financial autonomy. ${ }^{14}$ The judiciary was also granted administrative independence: higher courts were granted the exclusive right to propose bills relating to the creation of new courts or changes in the composition of existing courts, ${ }^{15}$ and since the 1988 Constitution, courts have been in charge of selecting and promoting their own judges, according to a meritocratic system. The reformers also strengthened the guarantees of tenure: after two years of probation, judges would have the guarantee of tenure until retirement, which is mandatory at age seventy. Their salaries were 'irreducible.' Furthermore, judges cannot be transferred from one court to another against their will. ${ }^{16}$ Higher courts hear administrative

12 Ibid. at 83; Carlos Santiso, 'Economic Reform and Judicial Governance in Brazil: Balancing Independence with Accountability' (2003) 10:4 Democratization 161 [Santiso, 'Economic']; Matthew M. Taylor, 'Citizens Against the State: The Riddle of High Impact, Low Functionality Courts in Brazil' (2005) 25 Brazilian J.Pol.Econ. 418 at 419 [Taylor, 'Citizens']; see also Matthew M. Taylor, Judging Policy: Courts and Policy Reform in Democratic Brazil (Stanford, CA: Stanford University Press, 2008) [Taylor, Judging Policy].

13 Prillaman, Democratic Decay, supra note 11 at 85-8; see also Santiso, 'Economic,' supra note 12 .

14 Prillaman, ibid. at 81.

15 Andrei Koerner, 'O Debate Sobre a Reforma Judiciaria' (1999) 54 Novos Estudos Cebrap 5 [Koerner, 'O Debate'].

16 Lei Orgânica da Magistratura Nacional (LOMAN), art. 26, c. II. 
disciplinary cases against lower court members, but the maximum administrative penalty is forced retirement, and the sentenced judge receives life retirement benefits in proportion to the time worked. In sum, the judiciary was given near total control over its financial, administrative, and disciplinary affairs. ${ }^{17}$

During the Constitutional Assembly there were discussions on mechanisms to ensure judicial accountability, such as judicial councils formed by judicial and non-judicial members. However, these were not approved, thanks to strong and organized opposition by judges, who dubbed the proposal a measure of 'external control' that would reduce courts' independence.$^{18}$ It is reasonable for Brazilian judges to fear external interference, given that such interference has happened many times in the past, including some traumatic episodes in recent Brazilian history. For instance, in 1977 the military president Geisel presented before Congress a bill to establish an 'independent' judicial council (conselho da magistratura) with power to discipline judges. When Congress rejected this proposal, Geisel approved the measure by decree. ${ }^{19}$ The council was likely created in order to assert political control over the judiciary. ${ }^{20}$ This may explain why the discourse about judicial independence had so much force within the constitutional assembly of $1987 / 1988$, and why it remained very much alive inside the judiciary in the following years.

In addition to judges' resistance to accountability mechanisms, there was not much popular support for their implementation. This may be explained by the existence of a public image of the Brazilian legal establishment as anti-authoritarian. This public image disregarded the involvement of civilian lawyers and judges in the military justice system and was largely based on 'the actions of the Bar Association in the justice and peace commissions that lobbied for an amnesty for political prisoners and protested human rights abuses in the 1970s, and the celebrity of a small group of lawyers who had defended political prisoners.' ${ }^{21}$

17 Prillaman, Democratic Decay, supra note 11 at 81.

18 Megan J. Ballard. 'Clash between Local Courts and Global Economics: The Politics of Judicial Reform in Brazil' (1999) 17 Berkeley J.Int'l L. 230 at 262 [Ballard, 'Clash']

19 Ibid. at 243.

20 Nuno Garoupa \& Tom Ginsburg, 'The Comparative Law and Economics of Judicial Councils' (2009) 27 Berkeley J.Int'l L. 52 at 69 [Garoupa \& Ginsburg, 'Judicial Councils'].

21 Anthony Pereira, 'Explaining Judicial Reform Outcomes in New Democracies: The Importance of Authoritarian Legalism in Argentina, Brazil, and Chile' (2003) 4:3 Hum.Rts.Rev. 3 at 7 [Pereira, 'Explaining']. 
B CONSEQUENCES OF THE 1988 REFORMS: MISMANAGEMENT OF RESOURCES AND CORRUPTION

The absence of effective external accountability mechanism to oversee the use of public resources, clear criteria for career advancement, and a wide array of administrative and disciplinary affairs led to financial recklessness, corruption, nepotism, and favouritism within the Brazilian judiciary.2 ${ }^{22}$ By the $1990 \mathrm{~s}$, cases of mismanagement of funds, granting of excessive individual benefits to judges, and corruption abounded. Carlos Santiso cites three examples of reckless expenditures in 1994: while the federal court system had a budget equivalent to about half a billion us dollars, it spent more than us $\$ 880$ million; the Higher Labour Court (TST) alone spent more than both chambers of Congress in one year; and the construction of a single luxurious building to serve as headquarters for the Superior Tribunal of Justice cost us $\$ 170$ million. ${ }^{23}$

As to individual benefits, William Prillaman provides the following information:

Judges, empowered to set up their own wages, pension, staffing requirements, and budgets, have treated themselves - particularly their upper ranks exceptionally well, with some of the world's most generous benefits. A Supreme Court justice earns US $\$ 10,800$ monthly - more than the President himself - while an average judge of first instance earns more than thirty times the national minimum salary. Judges do even better in retirement; Brazil's National Accounting Office has calculated that a typical judge of first instance earned US $\$ 2,393$ monthly in 1994 when serving on bench, but US $\$ 3,559$ when he retired - the only country in the world in which a judge earns more in retirement than when serving on the bench. ${ }^{24}$

In the late 1990s, cases of judicial corruption came to light. The most publicized case related to the construction of the São Paulo Regional Higher Labour Court (TRT/SP). Judge Nicolau dos Santos Neto, then president of TRT, was accused and eventually sentenced for leading a scheme that diverted to private bank accounts (including his own) more than us $\$ 90$ million from funds allocated to the construction of the Court's headquarters. ${ }^{25}$ This and other cases led the Senate to create a congressional commission of inquiry (in Portuguese, comissão parlamentar de inquérito, or CPI) to investigate abuses in the judiciary. The CPI conducted

22 Santiso, 'Economic,' supra note 12 at 9; Prillaman, Democratic Decay, supra note 11 at $85-7$.

23 Santiso, 'Economic,' ibid.

24 Prillaman, Democratic Decay, supra note 11 at 86.

25 Matthew M. Taylor \& Vinicius C. Buranelli, 'Ending Up in Pizza: Accountability as a Problem of Institutional Arrangement in Brazil' (2007) 49 Latin American Politics \& Society 59 at 71 . 
investigations of the case of the TRT/SP and of eight other cases from April to December 1999. The findings revealed the extent of the problem: commissioners found evidence of nepotism, financial irregularities, and corruption in both higher courts and lower courts in the states of Paraíba, Rio de Janeiro, Mato Grosso, Goiás, and Amazonas. ${ }^{26}$

\section{RESISTANCE TO REFORMS FROM 1988 THROUGH THE LATE 1990s}

Attempts to implement reforms to create greater judicial accountability began shortly after the 1988 Constitution was enacted. Nevertheless, the first meaningful judicial reform was approved only in 2004 (Constitutional Amendment 45), after seven years of intense political pressure. Why did it take so long to implement reforms that would bring more accountability to the Brazilian judiciary?

Trebilcock and Daniels advance three sets of potential impediments to the implementation of rule of law reforms in developing countries: resource-related impediments, socio-cultural-historical factors, and political economy problems. ${ }^{27}$ In the first case, the main stakeholders would show political will, but the lack of financial, technological, or human capital would impede the implementation of reforms. However, lack of resources is not a problem for the Brazilian judiciary: the federal courts in Brazil are 'well funded as a whole, with the highest budget in purchasing power parity terms per inhabitant of all the federal systems in the Western hemisphere. ${ }^{28}$

Trebilcock and Daniels show that a series of social values, norms, attitudes, and practices, which they loosely classify as socio-cultural-historical factors, may form a hostile environment for implementing reforms. A strong belief in the higher value of judicial independence vis-à-vis accountability within the judiciary may have played a role in the resistance offered by judges to reforms after 1988. This belief was reinforced by the country's recent history of reforms to promote judicial accountability (and especially judicial councils) that were actually attempts to undermine the independence of the judiciary, ${ }^{29}$ possibly combined with a positive public perception of the judiciary as a protector of human rights and the public interest. There are also reasons to believe that vested interests of members of the Brazilian judiciary (political-economy-based impediments) also played an important role. In this section, I build on

26 Senado de Noticias, Comissões (17 December 1999), online: Government of Brazil < http:// senado.gov.br/agencia/verNoticia.aspx? $\operatorname{codNoticia~}=8580 \&$ codAplicativo $=2>$.

27 Trebilcock \& Daniels, Rule of Law, supra note 3 at 39.

28 Taylor, Judging Policy, supra note 12 at 37 . The same is not necessarily true for state courts.

29 See notes 19 and 20 supra and accompanying text. See also Garoupa \& Ginsburg, 'Judicial Councils,' supra note 20 at 60 (suggesting that this is not unique to Brazil). 
Trebilcock and Daniels' typology of obstacles to reform to hypothesize that in Brazil these impediments were, paradoxically, created or significantly strengthened by the 1988 reforms.

As early as 1992, there had been proposals to create some form of external oversight of the judiciary. ${ }^{30}$ More intense debates occurred during the constitutional review process of 1993, wherein twelve of the eighteen proposals for judicial reform included some form of external oversight of the judiciary ${ }^{31}$ - none of which were carried forward. Like most other reform proposals during the 1993 constitutional review process, the discussion about constitutional reforms was clouded by the political turbulence following a corruption scandal involving twentynine members of Congress. ${ }^{32}$ Shortly before the aforementioned scandal, the Brazilian Congress impeached Fernando Collor de Mello (the first democratically elected president of Brazil since the end of the military dictatorship) on corruption charges. ${ }^{33}$ These events deprived both executive and legislative branches of the reputation, prestige, and influence they had at the time of the constitutional assembly. ${ }^{34}$ This may have impaired their ability to achieve substantial judicial reform.

In addition to this convoluted political context, judges and court employees played an important role in blocking these reforms by claiming that they would threaten judicial independence. ${ }^{35}$ This position on the part of the judiciary contrasted with broad support from other sectors of Brazilian society. The executive branch, most parliamentarians, the Bar Association, civil society organizations, and trade unions all vowed support for external oversight. ${ }^{36}$ Indeed, after 1993, proposals for judicial reform continued to be put forward by congressional representatives. These proposals included the creation of a national council to oversee

30 For a detailed analysis see Keith Rosenn, 'Judicial Review in Brazil: Developments under the 1988 Constitution' (2000) Sw.J.L.Trade Am. 291.

31 See Prillaman, Democratic Decay, supra note 11.

32 Timothy J. Power, 'Why Brazil Slept: the Search for Political Institutions, 1985-1997' (Paper presented at the 1997 meeting of the Latin American Studies Association, Guadalajara, Mexico).

33 For a more detailed account see Scott Mainwaring, 'Multipartism, Robust Federalism, and Presidentialism in Brazil' in Scott Mainwaring \& Matthew Shugart, eds., Presidentialism and Democracy in Latin America (Cambridge: Cambridge University Press, 1997) 55 at $94-7$.

34 Bolívar Lamounier, 'Brazil at an Impasse' (1994) 5 J.Democracy 72; Amaury de Souza, 'Collor's Impeachment and Institutional Reform in Brazil' in Keith S. Rosenn \& Richard Downes, eds., Corruption and Political Reform in Brazil: The Impact of Collor's Impeachment (Coral Gables, FL: North-South Center Press, 1998) 87.

35 Prillaman, Democratic Decay, supra note 11 at 97.

36 Prillaman writes that 'by 1994-95, 74 percent of the Congress declared itself in support of external controls on the judiciary, while 72 percent of the public expressed similar views.' Ibid. at 94. See Ballard, 'Clash,' supra note 18. 
the judiciary. ${ }^{37}$ Nevertheless, most judges continued to oppose the idea, and none of the proposals was implemented. Megan Ballard provides the details of judges' resistance:

Members of the Association of Judges for Democracy unanimously oppose any type of control that would interfere with the liberty of each judge to render his or her decisions. A survey of judges indicated that $86.5 \%$ of judges oppose external control over the judiciary. The Association of Judges of Brazil (Associação dos Magistrados do Brasil, or AMB) lobbied against external oversight, calling the measure unconstitutional 'nonsense' and claiming that it devalued judges. Likewise, most STF justices oppose external control on the grounds that it impairs judicial independence and have instead proposed a series of 'internal controls' by a council made up of appellate judges. ${ }^{38}$

Given a system that had allowed so many privileges and overlooked so many acts of judicial misconduct, it seems plausible to assume that vested interests played an important role in explaining the position of the judiciary.

In sum, since 1992 there has been increasing pressure to implement an independent judicial council in Brazil. However, the judiciary strongly resisted the suggested reforms for many years. This resistance was based on three factors, all connected with early reforms. First, there was a strong belief in the value of judicial independence, as this became the predominant discourse at the time of the early reforms, defining practices and attitudes of the members of the judiciary since 1988. Second, self-interested judges were not willing to restrain themselves by granting to other branches the ability to restrain the power they were initially granted. Third, excessive independence combined with lack of accountability opened up space for corruption and other vicious practices, and those benefiting from these practices did not want to surrender their benefits.

D CREATION OF THE EXTERNAL JUDICIAL COUNCIL (2005)

In the late 1990s, there was a partial change in the position of some associations of judges, and part of the judiciary started to accept the idea of a mechanism of control, but the resistance to the inclusion of representatives of non-judicial professions persisted. ${ }^{39}$ This shift was

37 In 1995 José Genoino, a member of the Workers' Party, presented a proposal to create state councils and a national council that would oversee the judiciary in budgetary and administrative matters. The Chamber of Deputies presented an alternative proposal in 1996 to create a National Council of Justice to oversee internal rules and hear complaints against the judiciary.

38 Ballard, 'Clash,' supra note 18 at 263.

39 Ibid. at 264. 
coupled with the 2002 election of President Luis Ignacio Lula da Silva ('Lula'), who made judicial reform one of his priorities. ${ }^{40}$ In 2003, Lula created a secretary for judicial reform within the Ministry of Justice to advance the government's proposal for reform, which included increasing judicial accountability in the form of external oversight. ${ }^{41}$ It was against this backdrop that the external judicial council was approved in December 2004 and implemented in 2005. The council is responsible for disciplinary action and for overseeing the budget and administrative matters. It is also responsible for compiling and publishing statistics about the workload and productivity of the judiciary. ${ }^{42}$

The judiciary initially opposed the idea of non-professional council members but were eventually defeated. The council is composed of nine judges, two lawyers, and two lay members appointed by the legislature. Despite a majority of judicial representatives on the council, judicial resistance continued after the council was created. The Association of Brazilian Magistrates challenged the constitutional amendment that created the council, arguing that the inclusion of members from outside the judiciary offended the principles of separation of powers and independence of the judiciary. The Brazilian Supreme Court affirmed its constitutionality (by seven votes to four). ${ }^{43}$

\section{Is it possible to avoid rule of law paradoxes and reform traps?}

In Part II above, I argued that the Brazilian case illustrates a reform trap, given that early reforms created obstacles to future ones. Reform traps occur when there are sequenced or piecemeal reforms, which can be defined as those that have one defined goal or objective, such as promoting judicial independence. Piecemeal reforms contrast with comprehensive reforms that have numerous objectives, such as creating an independent, accountable, efficient, and effective judiciary.4 ${ }^{44}$ Part III

40 Garoupa \& Ginsburg, 'Judicial Councils,' supra note 20 at 70 (discussing possible reasons why the Lula government supported this reform).

41 In addition to accountability, the government's agenda also included effectiveness and access to justice. For the difficulties faced by this secretary see Maria Angela Jardim de Santa Cruz Oliveira, 'Reforming the Brazilian Supreme Federal Court: A Comparative Approach' (2006) 5 Wash.U.Global Studies L.Rev. 99 at 137-8.

42 Constitutional Amendment no. 45 of 2004 (EC-000.045-2004); Brazilian 1988 Constitution, arts. 92 I-A and 103-B.

43 ADIN EC 45/2004.

44 There is a distinction between planned piecemeal reforms (the initial plan is all encompassing, but the implementation is phased) and a trial-and-error process in which future reforms are not previously planned. As Garoupa and Ginsburg suggest, the creation of judicial councils could be the result of a trial-and-error process wherein subsequent reforms are designed to tackle the problems created by earlier reforms: Garoupa \& Ginsburg, 'Judicial Councils,' supra note 20. See also Nuno 
asks whether adopting comprehensive reforms, instead of piecemeal ones, would be the solution to the reform trap problem. I discuss this in the particular context of judicial reforms. I suggest that comprehensive reforms present their own set of risks and, therefore, are not necessarily preferable to piecemeal reforms. Moreover, I argue that there are circumstances in which comprehensive reforms are not an option because path dependence can constrain the choices of reform strategies and make some reform options unavailable. This seems to be what happened in the Brazilian case.

\section{A THE RISKS OF COMPREHENSIVE REFORM}

The problem faced by Brazilian reformers back in 1988 was not a trivial one. How to balance judicial independence and judicial accountability is a question that generates much controversy both in the literature and in practice. Scholars have raised questions about what type of independence is to be promoted and protected ${ }^{45}$ and how much independence is desirable. ${ }^{46}$ These two goals are in permanent tension, because accountability mechanisms that allow for control and punishment can always be misused, reducing the level of independence of courts. ${ }^{47}$ As a consequence, reformers are left with the challenge of striking a delicate balance between these two goals, given that both independence and

Garoupa \& Tom Ginsburg, 'Guarding the Guardians: Judicial Councils and Judicial Independence' (2009) 57 Am.J.Comp.L. 103. It is not clear whether Brazil is the first or the second case. But it is important to acknowledge that if the Brazilian reforms followed a trial-and-error process, some of the problems identified in this paper would be a natural consequence of this process rather than an avoidable mistake in a consciously planned process. The distinction merits further analysis, but this is beyond the scope of the present essay.

45 Owen M. Fiss, 'The Right Degree of Independence' in Irwin P. Stotzky, ed., Transition to Democracy in Latin America: The Rule of the Judiciary (Boulder, CO: Westview Press, 1993) 55. See also Christopher Larkins, 'Judicial Independence and Democratization: A Theoretical and Conceptual Analysis' (1996) 44 Am.J.Comp.L. 605 at 623.

46 See Prillaman, Democratic Decay, supra note 11 at 17. See also Jorge Correa Sutil, 'The Judiciary and the Political System in Chile: The Dilemmas of Judicial Independence during the Transition to Democracy' in Irwin P. Stotzky, ed., Transition to Democracy in Latin America: The Rule of the Judiciary (Boulder, CO: Westview Press, 1993) 89.

47 Rogelio Pérez-Perdomo, 'Judicial Independence and Accountability' (Paper prepared for Comprehensive Legal and Judicial Development: Toward an Agenda for a Just and Equitable Society in the 21st Century, World Bank, Washington, DC, 5-7 June 2000), online: World Bank < http://www4.worldbank.org/legal/legop_judicial/ lj__conf_papers/Perez-Perdomo.pdf $>$. See also Michael Trebilcock, 'What Makes Poor Countries Poor: The Role of Institutional Capital in Economic Development' in Edgardo Buscaglia \& Robert Cooter (eds.), The Law and Economics of Development (Greenwich, CT: JAI Press, 1997) 15 (showing that there is also an inherent tension between institutional autonomy and institutional accountability in other areas, such as bureaucracy). 
accountability are key to a functional judiciary. ${ }^{48}$ In other words, reformers can be at a crossroads when trying to balance conflicting policy goals. ${ }^{49}$ In these cases, a reformer has at least two options: (1) to try to promote both goals simultaneously, trying to strike a balance between them; or (2) to favour one goal temporarily over the other. While the former will lead to full-fledged, all-encompassing reforms, the latter will lead to piecemeal and sequenced ones.

The piecemeal approach is intuitively very appealing: it seems straightforward, avoiding a 'broad based effort that strains state capability and risks getting bogged down in too many initiatives at once. ${ }^{50}$ However, favouring one goal over the other (even temporarily) carries significant risks. In judicial reform, for instance, if judicial accountability is favoured, there is a higher risk that external forces will attempt to influence judges' decision making, which may encourage them to rule in favour of what is popular, politically acceptable, or even personally advantageous. ${ }^{51}$ On the other hand, if greater independence is promoted, the danger comes from judges who are too free and thus use their position to pursue personal, professional, or political agendas at the expense of the rule of law. ${ }^{52}$

Prillaman provides concrete examples of these problems by examining the cases of judicial reforms in Argentina, Brazil, and El Salvador. These cases illustrate how the strategy of tackling one goal at a time means that while one area is being strengthened, other areas remain unreformed and flawed, and thus ultimately end up undermining the reform efforts by creating what Prillaman calls 'negative synergy.' His conclusion is that the assumption that one positive reform inevitably leads to another is fundamentally flawed. ${ }^{53}$ In contrast, Prillaman uses the case of Chile to support all-encompassing reforms. In Chile, reformers tackled what Prillaman describes as the major components of judicial reform independence, effectiveness, and access - at the same time maintaining some balance with judicial accountability. He states that under this approach, "no setback was overwhelming and no isolated reform was

48 For a map of the arguments in favour of greater independence or greater accountability see G. Allan Tarr, 'Creating and Debating Judicial Independence and Judicial Accountability' (Paper prepared for the 2006 convention of the American Political Science Association, 30 August-4 September 2006) [Tarr, 'Creating and Debating'].

49 For a more detailed discussion on how reformers and policy makers can be constrained by conflicting policy goals see Mariana Mota Prado, 'Policy and Politics: The Privatization of the Electricity Sector in Brazil' (JSD dissertation, Yale Law School, 2008) at c. 8.

50 Prillaman, Democratic Decay, supra note 11.

51 Tarr, 'Creating and Debating,' supra note 48.

52 Ibid. See also John A. Ferejohn \& Larry D. Kramer, 'Independent Judges, Dependent Judiciary: Institutionalising Judicial Restraint' (2002) 77 N.Y.U.L.Rev. 962.

53 Prillaman, Democratic Decay, supra note 11. 
undermined by the unreformed aspects of the courts; in short, there was no negative synergy as in the other cases.' ${ }^{54}$

As I have suggested above, piecemeal reforms impose yet another risk: early reforms favouring judicial independence can impose significant obstacles to the pursuit of judicial accountability in the future (the reform trap). The risk is not exclusive to judicial reforms but extends to other piecemeal reforms. For instance, Susan Rose-Ackerman argues that if anti-corruption reforms are not implemented early on in post-conflict societies, it may be hard to break a vicious cycle of corruption down the road. ${ }^{55}$

Prillaman argues that full-fledged reforms carry a reduced risk because they are more effective in avoiding undesired consequences. His argument acknowledges the fact that reforms often succeed because selfreinforcing mechanisms help keep institutional changes in place. ${ }^{56}$ However, he does not seem to acknowledge that while comprehensive judicial reforms can work quite well, as they did in Chile, they also involve many moving parts, and it is hard to predict how these parts will interact. Thus, Prillaman is correct in pointing out that institutional mechanisms in sequenced reforms will not necessarily be self-reinforcing (i.e., there is no certainty that some reforms will always follow others); yet, this also applies to comprehensive reforms: there is no guarantee that they will necessarily produce the predicted outcome. Indeed, Prillaman has only the case of judicial reforms in Chile to support his point. It does not follow from his analysis that if Brazil and Argentina had done what Chile did, they would have a better judiciary today. My point is that there are no guarantees that the Chilean reforms would achieve similar results in other countries.

Moreover, the effects of all-encompassing reforms, when they do not succeed, can be quite disruptive, and sometimes hard to reverse. ${ }^{57}$ These effects may outweigh the risks of the reform trap, which suggests that piecemeal reforms may be preferable to all-encompassing reforms under certain circumstances. ${ }^{58}$ Thus, reformers should be mindful that

54 Ibid. at 138.

55 Susan Rose-Ackerman, 'Corruption and Post-Conflict Peace-Building' (2008) 15 Ohio N.U.L.Rev. 328.

56 For an explanation of self-reinforcing mechanisms and their role in institutional reforms see Prado \& Trebilcock, 'Path Dependence,' supra note 8 at 350-3.

57 Ibid. at 367ff. Granted, Prillaman rejects sequenced incrementalism, but he does favour reforms that are comprehensive in scope but gradual in pace: Prillaman, Democratic Decay, supra note 11 at 4-7. See note 44 supra and accompanying text.

58 There are all-encompassing reforms that have multiple objectives but are limited geographically or by sector/institution. For instance, one can imagine a federal state in which the national government has the power to reform state courts. This national government could decide to implement reforms in the courts of a single 
sequencing is an important feature in designing successful reforms, as some sequences may impose greater risks of a reform trap than others..$^{59}$

There is no question that the particular option adopted in the Brazilian reforms created a reform trap. One might ask, however, whether Brazilian reformers had any other option. Could they have chosen between comprehensive and sequenced reforms, as Prillaman seems to assume? This is the question the next section tries to answer.

\section{B PIECEMEAL REFORMS AS THE ONLY OPTION}

In this section, I argue that path dependence can create obstacles to the implementation of all-encompassing reforms, as pre-existing economic, social, and cultural factors may impose switching costs to a new institutional regime. ${ }^{60}$ Because of these obstacles, piecemeal reforms may be the only option available.

Anthony Pereira has analysed the importance of path dependence in constraining the choices of rule of law reformers in transitional countries. He shows how prior authoritarian changes in the legal and judicial systems have influenced, constrained, or facilitated subsequent democratic or post-authoritarian judicial reforms. ${ }^{61}$ Like Prillaman, he looks at the cases of Argentina, Brazil, and Chile, arguing that judicial reforms in these countries were influenced by path dependency. In the Brazilian case, for instance, Pereira claims that

the Brazilian military regime of 1964-1985 was gradualist in its approach to the law, and had a high degree of civilian-military consensus in the legal sphere. It was not highly repressive in its deployment of lethal violence, and this combination of factors contributed to a gradualist and consensual transition in which judicial reform was not placed high on the political agenda. ${ }^{62}$

The case of Brazil thus contrasted with more violent dictatorships in Argentina and Chile. According to Pereira, 'the fact that the number of people affected by the repression was much less, in per capita terms, than in Argentina and Chile, also diminished the possibility of a backlash against the judiciary in the post-transition era. ${ }^{63}$ In Argentina, transitional

state; similarly, it could implement national reforms that apply only to certain courts, such as small claims courts, as opposed to being applicable to the entire judiciary. These limitations in dimension and scope could bring these reforms closer to piecemeal reforms, in the sense that they carry fewer risks than comprehensive judicial reforms that are implemented throughout the country and apply to all courts.

59 Prado \& Trebilcock, 'Path Dependence,' supra note 8.

60 Ibid. at 370.

61 Pereira, 'Explaining,' supra note 21.

62 Ibid

63 Ibid. at 7. 
reforms were specifically used as a backlash against the legal and political establishment.

Building on Pereira's argument, I want to suggest that path dependence will limit reform options because it will influence (if not determine) the structure of the bargain at the time of reforms. Judicial reforms in Brazil during the 1987/1988 constitutional assembly could be characterized as a bargaining process between a group demanding reforms and another group resisting reforms (those proposing and those resisting more accountability). Although this would be an accurate description of the situation after the 1988 Constitution was enacted, however, it may not be the best description of the bargaining process during the constitutional assembly. At that point, both groups wanted reforms to happen, and the point in dispute was that one group wanted greater independence, whereas another group lobbied for more accountability.

If this description is accurate, the structure of the bargaining process during the constitutional assembly is analogous to what Amartya Sen, in the household context, calls 'cooperative conflicts.' Sen shows that the husband and wife have a relationship of 'cooperative conflict': they value the mutual benefits of their relationship, but at the same time there are points where their interests conflict. ${ }^{64}$ Thus, family decisions will reflect balancing of common interests and bargaining over conflicting ones. The outcome of the bargaining process can be fairly egalitarian, or not. This idea of 'cooperative conflicts' is analogous to the reform process in Brazil because at the time of the constitutional assembly, judicial reforms were beneficial both to judges and to interest groups that lobbied for accountability. ${ }^{65}$

What can tip the balance in favour of one party in the bargaining process? According to Sen, in the household context the parties' relative bargaining power will affect the outcome (unequal bargaining power is more likely to lead to unequal outcomes) ${ }^{66}$ This relative bargaining

64 Amartya Sen, 'Gender and Cooperative Conflict' in I. Tinker, ed., Persistent Inequalities: Women and World Development (New York: Oxford University Press, 1990) 123 [Sen, 'Gender'].

65 The closeness of the analogy is particularly striking if one considers that in both cases it is not an if question but a how question. In judicial reforms, instead of asking whether we should be proceeding with reforms or not, reformers ask which, among all the possible alternative arrangements, is the most desirable. The same happens within the household. As Sen explains, '[w] omen seeking a better deal within the family are not proposing, as an alternative, the possibility of living without families. The bone of contention is whether the sharing of the benefits within the family system is seriously unequal in the existing institutional arrangements, compared with what alternative arrangements can be made.' Amartya Sen, Identity and Violence: The Illusion of Destiny (Cambridge: Cambridge University Press, 2006) at 135-6.

66 Sen, 'Gender,' supra note 64 at 133. 
power is determined in part by the relative position of each party in the status quo position. As Sen puts it, 'a more favourable placing in the breakdown position would tend to help in securing a more favourable bargaining outcome.' ${ }^{67}$ This could explain some of the unequal distributional outcomes within households, as in many countries some women can end up with no income and/or no wealth if divorce takes place. The breakdown position could also explain the judicial reform in Brazil, as the judicial branch did not have much to lose by simply maintaining the status quo: the Brazilian judiciary was one of the most independent in Latin America during the military dictatorship. ${ }^{68}$ In the Brazilian case, moreover, the judiciary's preferences are particularly relevant, because Congress delegated most of the judicial reforms of the 1988 Constitution to a group of experienced legal actors that included members of the judiciary, the Brazilian Bar Association, and human rights groups. ${ }^{69}$ As a consequence, members of the judiciary were able to negotiate the reforms directly with other interest groups, as the politicians with voting power were not interested in judicial reforms and were likely to defer to the decisions of this group. ${ }^{70}$ It is also relevant to note that in the transition to democracy, a political compromise guaranteed that the judiciary would absorb magistrates in the higher courts who had been politically connected to the military regime..$^{71}$ Thus, among the members of the judiciary there were people who had ties with the previous military regime. ${ }^{72}$ This circumstance also reinforces the idea that there is a path-dependent component in the political economy of rule of law reforms even during abnormal times.

As to social-cultural-historical factors, Sen identifies three that influence the outcome of the bargain within the household: perceptions of interest, conceptions of productive labour, and notions of legitimacy. ${ }^{73}$

67 Ibid. at 135.

68 Anthony Pereira, 'Of Judges and Generals: Security Courts under Authoritarian Regimes in Argentina, Brazil, and Chile' in Tom Ginsburg \& Tamir Moustafa, eds., Rule By Law: The Politics of Courts in Authoritarian Regimes (Cambridge: Cambridge University Press, 2008) 23.

69 Prillaman, Democratic Decay, supra note 11 at 79-80.

70 For a detailed discussion of the structure of this bargain see Adriano Pilatti, A Constituinte de 1987-1988 : Progressistas, Conservadores, Ordem Econômica e Regras do Jogo (Rio de Janeiro: Editora PUC-Rio, 2008).

71 Santiso, Economic,' supra note 12; Taylor, 'Citizens,' supra note 12; Taylor, Judging Policy, supra note 12; Prillaman, Democratic Decay, supra note 11.

72 Koerner, 'O Debate,' supra note 15.

73 In very simplistic terms, these three factors can affect the bargain as follows: depending on their perceptions of interest, which are very much culturally defined, women may lack a perception of personal welfare, and this may be combined with a greater concern for family welfare; with respect to conceptions about productive labour, some common social conceptions advance the idea that women's unpaid work 
It is possible to find analogous factors to explain the 1988 judicial reforms in Brazil. With respect to perception of interest, ${ }^{74}$ there was a lack of public interest in judicial reforms. ${ }^{75}$ Citizens did not seem to think that they were being deprived of anything by not having control over, or even access to information about, what the judiciary was doing. ${ }^{76}$ As mentioned earlier, Pereira suggests that the Brazilian legal establishment had a public image as an anti-authoritarian body. ${ }^{77}$ With respect to conceptions of productive labour, some reformers argued that there is a hierarchy of values between independence and accountability, in which the former trumps the latter; given the technical nature of the judicial function, they contended, methods of judicial accountability are nothing but undue political interference ${ }^{78}$ Finally, notions of legitimacy seem also to have affected the bargain in the 1988 judicial reforms. ${ }^{79}$ As Pereira observes,

[i]n Brazil, unlike in Argentina and Chile, reformers could not tap a sense among political elites that the judiciary had failed to protect democracy from the military and was somehow tainted by an authoritarian past. While a perception of the judiciary as inefficient was widespread, reformers had difficulty linking democratization with judicial reform. ${ }^{80}$

The difficulty in convincing Brazilian political elites of the need for judicial reform is partially explained by the fact that the political elite comprised a president with strong ties to the military regime and little concern with judicial reforms and a civilian political class with rather opportunistic motives, being more interested in obtaining the benefits associated with government service than with building an accountable

within the household is hierarchically inferior to paid work outside the household; and as to notions of legitimacy, women may not feel entitled to an additional share of the household wealth.

74 This is different from Trebilcock and Daniels' concept of entrenched interests. They are identifying 'real' interests, whereas Sen suggests that there may be a mismatch between 'real' and 'perceived' interests.

75 Prillaman, Democratic Decay, supra note 11 at 95.

76 It is important to distinguish between perceptions of interest and actual interests: Sen, 'Gender,' supra note 64 at 126 . The lack of strong popular demand for accountability mechanisms should not be interpreted as lack of an actual interest.

77 Pereira, 'Explaining,' supra note 21 and accompanying text.

78 This assumption comes from the idea that judges are highly educated professionals with specialized and expert knowledge in their field of practice. Subjecting these professionals to non-technical and non-expert control is often perceived as an undue and unnecessary interference in their jobs.

79 According to Sen, 'Gender,' supra note 64, within the household there is ambiguity with respect to perceptions of interest and notions of legitimacy. For instance, it is hard for a mother to conceive whether it is more legitimate to take the food for herself or to deprive herself for the benefit of the family.

80 Pereira, 'Explaining,' supra note 21 at 9. 
government. ${ }^{81}$ Those who were brave enough to excoriate the government for its subversion of human rights, democracy, and national sovereignty were eloquent orators but were not skilled in the art of identifying and representing citizen opinion. ${ }^{82}$ In short, the outcome of the bargain in judicial reforms is related to social-cultural-historical factors that are path dependent.

To conclude, path dependence can affect the choice of strategies that reformers might have. More specifically, there are situations in which a particular sequence of events will, at the same time, open up a window of opportunity for reform but give reformers no option but to favour one of two conflicting goals. This is largely what seems to have happened in the Brazilian case.

IV Getting out of reform traps

In Part II above, I highlighted how sequenced reforms can backfire, largely undermining broader reform goals and creating obstacles to future reforms (the reform trap). In Part III, I suggested that while avoiding sequenced reforms might be a solution, comprehensive reforms also involve risks, and in certain cases they are not feasible because of a series of path dependent constraints. In Part IV, I discuss whether there is a way out of the reform trap. More specifically, I hypothesize which factors might have played a role in breaking the deadlock in Brazil, and how they may shed light on potential solutions to the problems created by sequenced reforms.

My discussion will focus primarily on factors that could lead the interest group resisting reforms to modify its preferences. If we consider reforms as bargains, one possible strategy is to strengthen the weaker side of the bargain. ${ }^{83}$ However effective it might be, this strategy should not preclude us from asking whether there are also strategies that could make opponents of reform change their views. In the following sections, I identify three scenarios in which this change of position may occur. Trebilcock and Daniels propose the first scenario and part of the third one. The second scenario and the other half of the third are my additions to the list, and they are particularly relevant for this article because they could explain why judges in Brazil ultimately dropped their resistance to external control of the judiciary.

81 Prillaman, Democratic Decay, supra note 11 at 95.

82 Thomas Skidmore, The Politics of Military Rule in Brazil, 1964-85 (New York: Oxford University Press, 1988) at 267.

83 Ronald Daniels \& Michael Trebilcock, 'The Political Economy of Rule of Law Reform in Developing Countries' (2004) 26 Mich.J.Int'l L. 99 at 129-33 (items 2-5) [Daniels \& Trebilcock, 'Political Economy']. See also Prado \& Trebilcock, 'Path Dependence,' supra note 8 at $370-1$. 


\section{A REDUCING THE COSTS TO INTEREST GROUPS}

One way of overcoming interest groups' resistance is to reduce the costs they will incur if the reforms are implemented. As Daniel and Trebilcock explain,

if the many actors who are currently involved in a country's rule of law institutions legitimately fear that they will be summarily displaced or the illegitimate perquisites of public office eliminated when new institutions are created, then their resistance to reform is likely to be all the more intense. ${ }^{84}$

Reducing the costs that these actors will incur is likely to reduce their resistance to reforms. One way to reduce the costs to inexperienced and ill-trained individuals is to provide a combination of training, increased compensation, and accountability mechanisms. Another way is to offer transitional assistance such as buy-outs, early retirement benefits, relocation, and job-training subsidies. ${ }^{85}$

While these might be effective strategies in some cases, they do not seem applicable to reforms traps such as the one that existed in Brazil. In that case, there would be very little that could be offered to the vested group in terms of benefits to ease the transition: retraining will not reduce the costs to judges of becoming more accountable; their salaries are among the highest in the country ${ }^{86}$ and it is hard to envision a buy-out process similar to offering shares to workers in a newly privatized company. The only realistic way out of the Brazilian reform trap was the offer of early retirement benefits, which might trigger changes in the composition of the group. This is the topic to which I turn next.

\section{B CHANGING INTEREST GROUPS' COMPOSITION}

One important aspect of the reform process is the role of ideas. On the one hand, ideas can reinforce 'the lobbying efforts of certain pro-reform

84 Daniels \& Trebilcock, 'Political Economy,' supra note 83 at 133.

85 Ibid. at 133-4.

86 The Brazilian judiciary has the highest public-service salaries in the country. In December 2006 ministers of the Brazilian Supreme Court were earning two times more than congressional representatives, and three times more than the president of the Republic. Their salary is also much higher than the national average. According to the World Bank, the value of judges' salaries in Brazil in 1999 was more than thirty times the average salary in the country: 'Court Performance around the World - A Comparative Perspective' (World Bank Technical Paper No. 430, July 1999) at 23, online: World Bank $<$ http://www4.worldbank.org/legal/leglr/>. This conclusion was reaffirmed in 2004: Nelson Marconi, Laura Carrilho, \& Claudia Helena Cavalieri, La Remuneración de los Altor Dirigentes del Sector Público un Análises sobre los Páises de América Latina y el Caribe (Centro Latinoamericano de Administración para el Desarrollo - CLAD and Inter-American Development Bank, 2004), online: Globo.com <http://epoca.globo.com/ rev_eletronica/ep446/judiciario.pdf $>$. 
lobby groups. ${ }^{87}$ On the other, ideas can play a role in mitigating resistance from interest groups. As suggested earlier, many actors within the Brazilian judiciary believed that judicial independence trumps any form of external accountability; thus, mitigating the resistance of this group may require changing their opinions and values with respect to judicial independence.

One way to change the values of a group is by changing its composition. As older judges who were connected with the military regime retire and younger judges, born and raised during the democratic period, start to join the judiciary, the balance may start tipping in favour of greater accountability even within groups inside the judiciary. Indeed, based on opinion polls, Joaquim Falcão shows that there is significant divergence in opinions on judicial independence between lowercourt judges, who tend to be younger, and higher-court judges, who tend to be older (in Portuguese, juizes and desembargadores). Opinions also diverge with respect to the control of corruption and abuses: while 71 per cent of lower-court judges are against nepotism, only 58.4 per cent of higher-court judges think that nepotism should be forbidden in the judiciary. ${ }^{88}$ Since 1988, the number of younger judges has progressively increased in the judiciary (mostly in the lower courts): by 2005, 28.4 per cent of judges were forty years old or younger, and 53.1 per cent were up to 50 years of age. ${ }^{89}$ According to Falcão, younger judges are more sensitive to the increasing popular demand for ethical conduct and protection of the public interest in different branches of government. This may at least partly explain why some actors within the judiciary changed their position and decided to support some form of external control in the late $1990 \mathrm{~s} .{ }^{90}$ If this is true, incentives for early retirement might speed up the process of 'rejuvenating' ideas within an institution that is resisting reform.

Younger judges did not have much voice within the hierarchical structures of the judiciary, but they acquired significant political power by joining professional associations of judges (civil society organizations outside the judiciary).${ }^{91}$ Associations of judges were an institutional innovation not predicted by the 1988 Constitution; nevertheless, these associations became politically relevant by representing judges in discussions of bills and proposed reforms before Congress, and they also brought

87 Daniels \& Trebilcock, 'Political Economy,' supra note 83.

88 Joaquim Falcão, 'O múltiplo judiciário' in Maria Teresa Sadek, ed., Magistrados: uma imagem em movimento (Rio de Janeiro: Editora FGV, 2006) 115 at 125-7.

89 Ibid.

90 No study has yet been conducted to assess whether younger judges played an active role in promoting accountability within the judiciary in Brazil.

91 Falcão, 'O múltiplo judiciário,' supra note 88; see also Koerner, 'O Debate,' supra note 15 . 
judges' voice to the media. Because their internal structure does not reflect the judicial hierarchy, younger judges can hold positions of power. These associations so closely reflect the opinions and preferences of younger judges that older judges have now created an association of their own to better protect their interests. ${ }^{92}$ The associations seem to have been a driving force in reducing judicial resistance to greater levels of judicial accountability. As Ballard explains,

Despite widespread opposition of judges, both the AMB [Brazilian association of Magistrates] and another group of judges, the Association of Federal Judges (AJUFE), recently capitulated to the idea of external control. ... The AMB stated its willingness to consider an oversight council made up of judges but conceded that lawyers could play a role in selecting judges. The federal judges organization went a step further when it stated in January 1999 that it would support an oversight body to manage administrative questions..$^{93}$

This is an example of an institutional innovation that gave a voice to younger judges within the Brazilian judiciary. The most recent constitutional amendment, which created the external council, has changed some of the internal governance structures of higher courts so as to allow for greater participation of younger judges. ${ }^{94}$ Thus, 'rejuvenating' a resistant institution with fresh blood and new ideas may also require some creative institutional measures that will empower new members and allow them to voice their preferences more effectively.

\section{MAKING INFORMATION AVAILABLE}

Daniels and Trebilcock suggest that rule of law reformers need to prioritize meaningful, independent, and transparent monitoring of performance to assess whether institutions are operating in an efficient, non-corrupt and accountable manner. ${ }^{95}$ On the one hand, the Brazilian experience largely confirms the assumption that secrecy and lack of accountability will lead to mismanagement of resources, abuses, and corruption. On the other hand, it also shows why reformers may not be able to implement the mechanisms of accountability that Trebilcock and

92 Consultor Juridico, 'Desembargadores criam a Andes, associação nacional da classe' (10 March 2006), online: Consultor Juridico < http://www.conjur.com.br/2006-mar10/desembargadores_criam_associacao_nacional_classe $>$.

93 Ballard, 'Clash,' supra note 18 at 264.

94 See, e.g., Brazilian 1988 Federal Constitution, art. 93, XI, establishing that management bodies within tribunals with more than twenty-five judges will be composed both of the most senior judges (who have been judges for longer periods) and judges elected by their peers to occupy these positions. This system replaced one in which these management bodies were composed solely of older judges (those who had held their positions for longer periods).

95 Daniels \& Trebilcock, 'Political Economy,' supra note 83. 
Daniels deem advisable (at least, not in the first generation of reforms). The question I ask in this section is whether availability of information may help to mitigate resistance and create an opportunity for a second generation of reforms. In Brazil, corruption scandals and information about nepotism and mismanagement of resources strengthened the position of groups lobbying for greater judicial accountability. But did it also help mitigate resistance by interest groups?

One reason that availability of information may allow for a second generation of reforms is that making information about corruption, mismanagement, and abuses public creates reputational costs for the actors involved, which, according to Daniels and Trebilcock, reduce their incentives to support the status quo. ${ }^{96}$ This seems to describe, at least in part, what happened in Brazil. Some authors suggest that the increasing lack of popular support and legitimacy may explain the partial change in the position of judges. In particular, in the late 1990s, the series of scandals involving members of the judiciary - which led to the creation of the parliamentary commission to investigate corruption and other forms of judicial misconduct - further undermined the public trust in the courts, which had already been declining. ${ }^{97}$ Judges not involved in mismanagement of resources, favouritism, and corruption may have decided to differentiate themselves from the rest of the judiciary by adhering to the proposal for greater accountability. Thus, reputational costs potentially explain why parts of the judiciary began to favour proposals for an external judicial council in the late 1990s. ${ }^{98}$

Another reason that availability of information may help mitigate resistance to reforms is related to the existence of social-cultural-historical factors that create obstacles to reforms. The reputational costs hypothesis separates rent-seeking judges from the rest; in this respect, it shows that availability of information makes resisting reform costly for those currently benefiting from the status quo. This hypothesis addresses the political economy problem. In contrast, social-cultural-historical factors suggest that honest judges may have had principled reasons, rather than selfinterested ones, for preferring greater independence over increased accountability. It is harder to explain a shift in principled resistance to reform, but such a shift might be connected with the availability of information. One hypothesis is that an honest judge who highly values independence could be forced to reconsider in light of information suggesting systemic abuse, favouritism, and rampant corruption in the

96 Ibid.

97 Taylor, 'Judging Policy,' supra note 12 at 43; see also Ballard, 'Clash,' supra note 18.

98 The Brazilian case suggests that it is not enough merely to provide access to information; rather, those who have access need to be able to make effective use of it (which normally depends on access to resources). 
judiciary. If values and interests are viewed as dynamic and endogenous to the political process, availability of information can provide incentives for people to rethink their values.

V Conclusion

Institutions matter for development. However, we know very little about how to implement institutional reforms that will be long-lasting and conducive to development. The rate of failure in rule of law reforms is high, generating more and more disappointment. Michael Trebilcock's work has contributed a great deal to our understanding of why this happens. In his latest book with Ron Daniels, he has mapped the obstacles to institutional reforms in general, and rule of law reforms in particular. In this article, I have used Trebilcock and Daniels' map to discuss the paradoxical situation in which early reforms backfire, undermining the entire reform effort and creating obstacles for second-generation reforms (the reform trap). It is nearly impossible to talk about law and development today without engaging with Michael Trebilcock's scholarship. It is therefore a privilege and an honour for me to work so closely with him, and I very much look forward to continuing our collaboration. 